\title{
Whiteness in Latin America: measurement and meaning in national censuses (1850-1950)
}

Mara Loveman

\section{(2) OpenEdition}

12 Journals

Electronic version

URL: https://journals.openedition.org/jsa/11085

DOI: 10.4000/jsa.11085

ISSN: 1957-7842

\section{Publisher}

Société des américanistes

\section{Printed version}

Date of publication: 5 December 2009

Number of pages: 207-234

ISSN: 0037-9174

\section{Electronic reference}

Mara Loveman, "Whiteness in Latin America: measurement and meaning in national censuses (1850-1950)", Journal de la Société des américanistes [Online], 95-2 | 2009, Online since 10 December 2014, connection on 03 September 2022. URL: http://journals. openedition.org/jsa/11085 ; DOI: https://doi.org/10.4000/jsa.11085 


\title{
WHITENESS IN LATIN AMERICA: MEASUREMENT AND MEANING IN NATIONAL CENSUSES
}

$(1850-1950)$

\author{
Mara LOVEMAN *
}

Drawing on an analysis of all national censuses conducted in Latin America from 1850 to 1950 , this article examines how tacit assumptions about the nature of " whiteness » informed the production of statistical knowledge about Latin American populations. For insight into implicit racial beliefs that shaped census-taking in this period, the article considers how census agents accomplished three basic tasks: 1) identifying the " race » of individuals in the population; 2) preparing statistical tables to publicize census results; and, 3) projecting the racial composition of national populations in the future. The analysis identifies variation in notions of " whiteness » across the region, but also points to a set of broadly shared premises about the nature, value, and boundaries of whiteness that transcended nation-state boundaries in this period. Fundamental similarities in ideas about whiteness found in Latin American censuses appear even more starkly when the scope of analysis expands to include the censuses of the United States. [Key words: census, race, racial classification, whiteness, Latin America.]

Les Blancs en Amérique latine: mesure et signification dans les recensements nationaux (1850-1950). Fondé sur l'analyse de tous les recensements nationaux effectués en Amérique latine entre 1850 et 1950 , le présent article examine la façon dont certains paradigmes tacites sur la "blancheur » ont modelé la production de connaissances statistiques sur les populations latino-américaines. Afin de clarifier les croyances raciales implicites qui se sont exprimées dans ces recensements, l'article distingue trois opérations de base effectuées par les agents du recensement: 1) identifier la « race » de chaque individu; 2) préparer des tableaux statistiques pour la publication des résultats; 3) projeter la future composition raciale de la population nationale. L'analyse identifie des variations dans la notion de « Blanc » à travers la région, mais révèle aussi une série de paradigmes largement partagés sur la nature, la valeur et les limites de ce qu'est un Blanc, qui traversait les frontières nationales de l'époque. La recherche conclut que les similitudes régionales en Amérique latine sur la signification de la " blancheur » sont encore plus remarquables quand on les compare avec les paradigmes implicites et explicites sur la «blancheur » dans les recensements des États-Unis pendant la même

* Associate professor of sociology, University of Wisconsin, 8128 William H. Sewell Social Science Building, 1180 Observatory Drive, Madison WI 53706-1393 [mloveman@ssc.wisc.edu].

Journal de la Société des Américanistes, 2009, 95-2, pp. 207-234. OSociété des Américanistes. 
période. [Mots-clés: recensement, race, classification raciale, blancheur, Amérique latine.]

La blancura en América Latina: medición y sentido en los censos nacionales (1850-1950). A partir del análisis de todos los censos nacionales realizados en América Latina entre 1850 y 1950, este artículo examina cómo las premisas tácitas sobre la «blancura » formaron parte de la producción del saber estadístico sobre las poblaciones latinoamericanas. Con el fin de esclarecer las creencias raciales implícitas que se plasmaron en los censos de este período, el artículo distingue tres funciones básicas realizadas por los agentes del censo: 1) identificar la "raza » de cada individuo; 2) preparar cuadros estadísticos para publicar los resultados; 3 ) proyectar la composición racial futura de la población nacional. El análisis identifica variaciones en las nociones de la «blancura » a través de la región, pero también establece un conjunto de premisas ampliamente compartidas sobre la naturaleza, el valor, y los deslindes de la "blancura ", que sobrepasaban las fronteras nacionales de esa época. Estas premisas compartidas son aún más notables cuando se comparan con las premisas implícitas y explícitas sobre la « blancura » que informaban los censos de los Estados Unidos de América durante el mismo período. [Palabras claves: censo, raza, clasificación racial, blancura, América Latina.]

The explicit identification of " whiteness » as an object of study was a radical intervention in race scholarship in the United States, destabilizing the long tradition of identifying ethnic and racial studies with the study of ethnic and racial minorities and their problems. As part of the social constructivist re-reading of the history of race in America, the critical study of whiteness has rendered visible the fact that « white »-like other racial and ethnic categorical identifications - is a social and historical, rather than a natural kind of person to be. The objectification of whiteness denaturalized the previously unmarked reference group in studies of race, and fueled the explosion of «whiteness studies » across several different disciplines ${ }^{1}$.

Taken together, the varied contributions to whiteness studies scholarship have drawn attention to the many forms of invisible privilege that accrue to those seen as « white » in the United States. At the same time, this literature has made clear that the boundary of whiteness in the United States - that is, the social and symbolic line demarcating who is white from who is not - has changed over time. Despite its naturalization as fixed, impermeable, and enduring, the boundary that demarcates who is white has broadened in some moments and contracted in others, and it has been more or less permeable for distinct « kinds » of individuals who have aspired to cross it.

While the cascade of scholarship on whiteness in the United States continues to grow ${ }^{2}$, the pivotal notion that the category " white " is defined socially and historically has arguably made much less of a splash in scholarship on race in Latin America. Indeed, there does not appear to be an analog in Latin Ameri- 
canist scholarship to the interdisciplinary field of " whiteness studies " that has coalesced in the United States. No doubt this owes largely to the very different histories of racial division and resistance in the US and the individual countries of Latin America, differences that are refracted, to varying degrees, in the production of scholarship on race and ethnicity in each context. But perhaps it is also because what appeared in the United States as a radical and destabilizing analytical move, in the Latin American contexts comes as a somewhat peculiar version of rather old news. The idea of whiteness as an achieved social status - that individuals, families, even entire communities may move across racial boundaries to become white - was a central focus of scholarship on race in Latin America long before the recent surge of whiteness studies in the United States.

The topic of whiteness has certainly not been ignored in scholarship on race in Latin America. Yet it has rarely been the principal focus of investigation either. Studies of whiteness in the US suggest that making the " white » racial category a central focus of analysis, placing it directly beneath the objectifying lens, may yield new insights into the social production and reproduction of racial hierarchy. Sustained attention to how the category " white » is defined and deployed in particular contexts can help to illuminate how, exactly, race becomes naturalized. Precisely because " white » is so often the reference category in discussions of racial dynamics (in daily practice as in scholarship), problematizing the takenfor-grantedness of «whiteness » may advance understanding of how racial categories work to make social differences appear to be natural differences.

While it may not make sense to simply transpose the entire " whiteness studies » agenda from the US to Latin America, some central concerns from this varied field of scholarship could prove to be productive lines of inquiry for advancing comparative understanding of racial dynamics in Latin America. There are by now a number of very rich anthropological, sociological, and historical accounts of the racial dynamics of individual Latin American countries during specific historical periods. Recent contributions have focused especially on the place of blackness and indigeneity in national constructions in the region ${ }^{3}$. Since racial and ethnic identities are constructed relationally, these studies contain within them a wealth of insights - sometimes implicit and sometimes explicit - into the meaning and social significance of whiteness in many parts of Latin America. Building from these recent contributions, and taking a cue from whiteness studies in the US, we might pose a number of comparative questions that specifically aim to unpack the social meaning of whiteness in Latin America in comparative and historical perspective.

Among the questions that might be posed by a critical study of whiteness in Latin America: How similar or different are understandings of "whiteness » across Latin America and within individual countries or localities over time? How were the boundaries of whiteness constructed historically in different parts of Latin America? What are the symbolic and material consequences of inclusion 
in the category « white » in different parts of the region at different points in time? What are the social penalties for exclusion from the white racial category in comparative-historical perspective? Who could aspire to inclusion, in which contexts, and at what cost? To what extent are there hierarchies within the « white » racial category in different Latin American contexts, and do intra-white distinctions (e.g., based on nationality or religion) affect how the boundary between "Whites » and " non-Whites » is conceived? In what ways do understandings of whiteness found in Latin America map onto understandings found in the US, and in what ways do they differ? Is " white » always the unmarked racial category in Latin America in the same way it is presumed to be in the United States? Of course, these questions do not exhaust the possible lines of inquiry into the social significance of whiteness in Latin America. Rather, they direct attention towards a promising new terrain for comparative research on the creation and maintenance of racialized social inequality in the Americas.

The present contribution does not pretend to encompass all of this vast terrain. The more modest aim of this article is to suggest the potential for comparative analysis of constructions of whiteness in the Americas through a close examination of the use of the category « white » across the entire region in one very specific context: national censuses. National censuses are usually used by researchers to glean information about the size, composition and characteristics of populations. But they can also be read as historical texts, as cultural and political products that provide clues to the tacit assumptions and ideologies that influenced their creators ${ }^{4}$.

Based on a critical review of every available national census conducted in Latin America from Independence to the present day, this article analyzes how tacit assumptions and explicit beliefs about the nature of race in general, and the nature of "whiteness » in particular, informed the production of statistical knowledge about the racial make-up of Latin American populations. The analysis focuses especially on national censuses conducted between 1850 and 1950 that included a direct " race » query on the census schedule (the rationale for this focus is discussed below). For all such censuses, I examined the format of questions, the instructions to enumerators, the presentation of racial statistics in official published results, and any accompanying narrative discussion or analyses.

Needless to say, there is much variation in the census schedules and statistical descriptions of populations contained in Latin American censuses in this period. Without ignoring important axes of variation, however, the central aim of the present analysis is to identify points of convergence in conceptions of " whiteness $\gg$ that informed census-taking in the region. The reasons for this choice of emphasis are twofold. First, it is not possible within the space of a single article to fully describe, much less account for, the many differences in the production of racial statistics across all the countries of Latin America or the often nuanced changes in enumerative practices within individual countries over time ${ }^{5}$. Second, 
without forgetting that nomothetic aspirations typically come at an idiographic cost, it can be fruitful to momentarily bracket the exploration of historical differences to entertain the possibility of shared understandings, practices, or beliefs across the most varied circumstances. The identification of points of convergence in understandings of « race " across contexts, in turn, can bolster the analysis of racial meanings in specific cases, by serving as a point of reference against which historically contingent idiosyncrasies of racial thought and practice in disparate settings can be assessed.

Thus, the present analysis asks whether - or to what extent - national censuses in Latin America from 1850-1950 reveal shared assumptions about the meaning of " whiteness ». Analysis of original census documents and published results suggests that certain fundamental understandings about the nature, value, and boundaries of whiteness transcended nation-state borders. Without arguing that there was (or is) a single, unitary, "Latin American " understanding of whiteness, the analysis reveals that in certain key respects, tacit assumptions about the nature of whiteness appear quite similar in the national censuses of diverse Latin American countries. Further, implicit understandings of the nature, value, and boundaries of whiteness evident in the national censuses of Latin American countries bear much more resemblance to each other than to the understandings of whiteness that informed racial enumeration in the national censuses of the United States.

The analysis that follows examines conceptions of whiteness in Latin American censuses by comparing how census-takers across countries accomplished three basic tasks entailed in the production of official racial statistics in this period: 1) the identification of "Whites » in the population; 2) the presentation of statistical tables describing the results, and; 3 ) the projection of the racial composition of the population in the future. The analysis emphasizes points of convergence in the measure and meaning of "whiteness " in Latin American censuses, but also notes some points of divergence across distinct contexts in the Americas. Before proceeding to the analysis, I provide an overview of the set of texts upon which this study is based and comment briefly on the significance of national censuses in the history of state and nation-building in Latin America.

\section{RaCiAL CLASSIFICATION IN LATIN AMERICAN CENSUSES}

It may initially seem an odd choice to examine national censuses from nineteenth and early twentieth century Latin American for clues to tacit understandings about the meaning of the " white » racial category in the region. After all, at independence the Spanish American republics defined themselves in direct opposition to the legally inscribed ethnoracial hierarchy imposed by the Spanish colonial state. In their origins, the Latin American republics explicitly rejected 
- at least rhetorically - the practice of official racial classification. Nonetheless, the vast majority of Latin American republics (and monarchical Brazil) opted to classify their populations by "race» in at least one national census in the nineteenth or early twentieth century.

Figure 1 presents a synoptic view of the national censuses conducted by Latin American states from Independence to the present day. Cells shaded in light grey indicate that a country conducted (or attempted to conduct) a national census in that decade ${ }^{6}$. Cells shaded in grey indicate that a census in that decade included an explicit " race » or " color » query. Blank cells indicate that no census was conducted in that decade. A question mark indicates a census was reportedly taken in a given country and decade but I have not been able to consult original sources to verify the content of the census questionnaire.

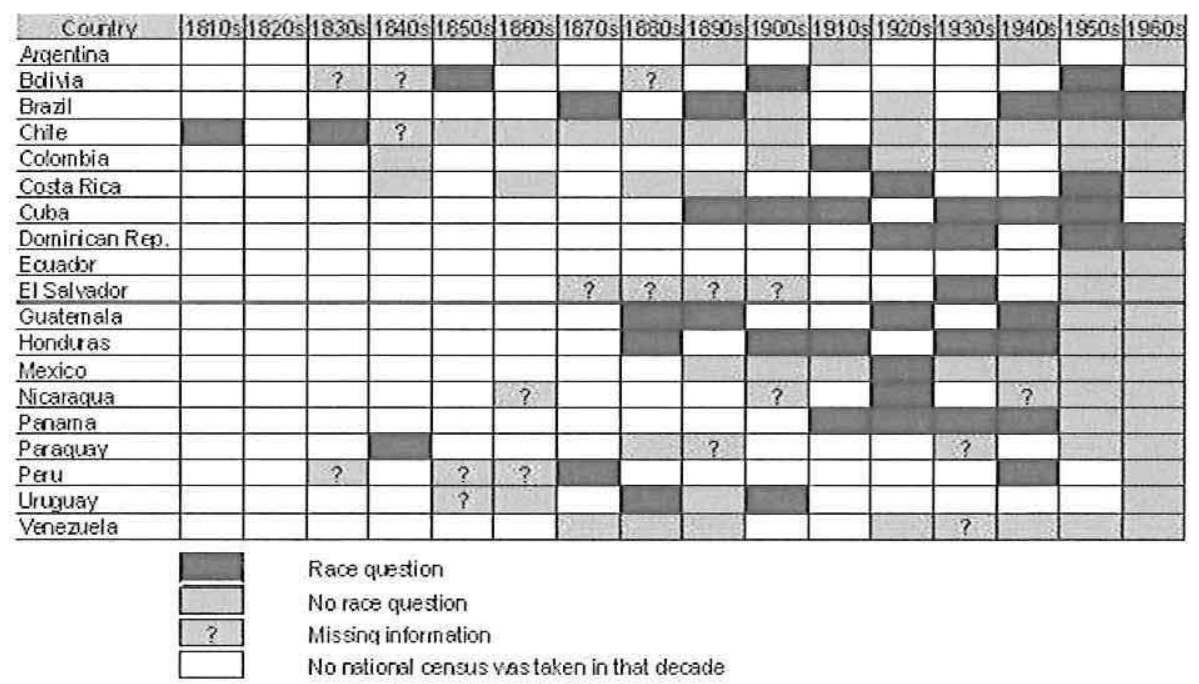

FIG. 1 - Race queries in Latin American censuses, 1810s-1960s.

Sources: Data is compiled from microfilm and print copies of original census schedules, reports, and results archival and secondary sources that reference specific censuses; information available online at the official website of each country's national statistics agency and information contained in Goyer and Domschke (1983) and Platt (1989). Information from non-primary materials was cross-checked with primary source material whenever possible.

Notes: a) "Race question » indicates a query that used the term raza (raça) or color (côr) or asked "Is [the person]... " followed by a choice of racial categories; b) in ten cases, more than one national census was conducted in a given decade. In these cases, the cell is shaded if either census or both included a race question; c) clarifying notes about several individual cells in Figure 1 have been omitted due to space constraints.

From this large set of national censuses, the present article focuses especially on those conducted between 1850-1950, paying particular attention to censuses that included an explicit « race » query, or omitted such a query but nonetheless 
discussed racial statistics in published census results ${ }^{7}$. There are both practical and theoretical reasons for this delimited focus. Practically, it makes sense to start in the 1850s rather than immediately after Independence because so few Latin American countries attempted to conduct a modern national census in the first decades of the nineteenth century. There are reported attempts in a handful of countries, but with the exception of Chile in 1813 and 1835, very little is known about these early initiatives ${ }^{8}$. Between 1850 and 1950, every Latin American country took at least one national census and the majority asked directly about « race » or " color » at least once in this period. This broad temporal scope thus allows consideration of the full set of Latin American countries - those that started census-taking relatively early, and those that started later. By the 1960s, in turn, the majority of Latin American countries abandoned the use of direct « race » or " color » queries in national censuses 9 .

There are also strong historical and theoretical reasons for focusing on the second half of the nineteenth century and the first half of the twentieth. In 1850, the International Statistical Congress convened for the first time in Brussels and issued an influential recommendation that all modern states should take periodic national censuses of their populations. Thereafter, census-taking took on increased symbolic and political importance for modernizing states worldwide ${ }^{10}$. In Latin America, taking a national census became a symbolically potent way to substantiate claims to membership in the club of "modern, civilized nations $"$.

Written in the internationally prestigious language of statistics, and sanctioned by the combined authority of science and the state, censuses played featured roles in state and nation-building projects throughout Latin America " . From the latter half of the nineteenth century, national censuses came to be seen as indispensable instruments for assessing - and publicizing - the progress of modernizing Latin American nations. Of course, the precise timing and role of statistics agencies' contributions to state and nation building varied across countries and within countries over time. But throughout the region, published volumes of census results were seen as indispensible evidence and instruments of modern statehood, providing scientifically « objective » renderings of the present and future " face of the nation " ${ }^{12}$.

In part, the political import of national censuses owed to their simultaneous domestic and international legibility. Both the narrative and statistical content of nineteenth and early twentieth-century census publications makes clear that their authors were oriented to domestic concerns and international ideological currents at the same time. With this dual audience in mind, census publications were carefully crafted as « scientific " portraits of the nation.

Using statistics as their principal medium, these national portraits helped to forge the tight linkage between ideas about "race» and ideas about modern nationhood in late nineteenth and early twentieth century Latin America. Indeed, 
Latin American census publications from 1850-1950 are exceptionally rich sites to investigate how the racial classification of populations was tied to nationmaking projects in different parts of Latin America and in the region as a whole. As one small part of this larger theoretical agenda, the analysis that follows examines the conceptions of "whiteness" that informed the production of national statistical portraits in Latin America from 1850 to 1950. By exploring how tacit beliefs about the nature, value, and boundaries of whiteness shaped official statistical descriptions of national populations, the analysis highlights the role of censuses in yoking ideas of race and nation in Latin America, while also pointing to the potential for new lines of comparative research on the social significance of « whiteness » in the Americas.

\section{THE NATURE OF WHITENESS: WHO IS WHITE?}

Up until the mid-twentieth century, when a « race » query was included on a national census schedule it was standard practice for census enumerators to assign individuals' racial classification. Self-identification only became the preferred method of enumeration after World War II; before that, enumerator ascription was almost always the oflicial method for collection of racial data in censuses throughout the Americas ${ }^{13}$. In order to improve the quality and consistency of the data collected in this manner, census agencies often issued explicit instructions to enumerators describing how to fill in the official forms. These official instructions, together with the format of questions and the allowable responses, can be read as cultural artifacts. They provide clues to tacit assumptions about the nature of « race » as an object of statistical investigation ${ }^{14}$.

What do the official questions, categories, and instructions for racial classification in censuses reveal about official conceptions of whiteness in Latin America in this period? While the specific answer to this question varies by country, certain shared assumptions about the nature of race in general and the nature of whiteness in particular are evident from census schedules from across the region. In particular, there appears to be broad consensus in the tacit understanding of " race » as an objective individual trait discernible through simple sight, at least most of the time. There also seems to be a shared assumption that « whiteness » is even more self-evident than other self-evident racial types. Finally, there is suggestive evidence that « whiteness » is understood to be bound up with ideas of familial honor in many parts of the region.

The broadly shared assumption that "race» is a self-evident, objective property of individuals can be seen in the format of race queries in Latin American censuses. Queries about race on Latin American censuses before WWII generally took the form of one-word prompts rather than full questions. The word raza or color would appear on the census form, followed by a blank line. 
Some census schedules dispensed with any prompt whatsoever, leaving a simple blank to be filled in with one of a set of predetermined categories. The format of these queries suggests that « race » was not considered a matter of « identity » or of communal belonging, as it came be defined in the censuses of some countries of the Americas towards the end of the twentieth-century and beginning of the twenty-first. Rather; " race » was construed as an essential individual trait, as something a person just is.

Given this understanding of race, census enumerators were tasked with the job of reporting individuals' race by selecting the « correct » racial category from a finite set of official options. The specific terminology and number of categories that enumerators could choose from varied across countries and often within countries over time. Typically, the set of categories included some combination of "white» (blanco), " black» (negro), "indian » (indio or indigena), and « mixed» (usually denoted with mestizo and/or mulato, but ladino, trigueño, pardo, and mezclado also appeared in some cases). Some censuses also included amarillo as an official category, though this category was sometimes omitted in the presentation of results ${ }^{15}$. The inclusion of an "other" option in many contexts signaled recognition that the official category set was not comprehensive of all "races" that might be identified in national populations, while also implying the state's disinterest in the categorical identification of any « racial kinds " not already conceived as constitutive elements of the nation.

Notably, while there is considerable variation across countries and over time in the availability and terminology of categories to describe individuals of African, indigenous, "mixed » or « other » descent, there is almost no such variation with respect to the category « white ». With very few exceptions, every Latin American census that includes a direct « race » query lists « white » as an official option ${ }^{16}$. Among the exceptions are the 1880 Guatemalan census and the 1887 Honduran census, which employed the dichotomous category set ladino or indigena, and the 1950 Bolivian census, which simply recorded if individuals were indigenous or not (indigena or no indigena). These cases highlight a binary racial vision in some parts of Latin America, where the line dividing « Indians » from the rest of the population was elevated above other possible lines of differentiation. The narrative texts accompanying the published census results in these cases (discussed below) leave little doubt that the ladino or no indigena classification was strongly associated with whiteness - though a whiteness understood to hinge much more on distance from "indianness» than on notions of «purity of blood».

From the perspective of those who wrote up instructions for census enumerators, the question of whom to count as « white » on the census was not treated as problematic. The same definitely cannot be said of other racial categories. While explicit instructions to enumerators for filling in the « race » field on census forms were not routine (testifying, again, to the presumed self-evidence of 
" race »), in the cases where enumerators were given written instructions for completing this task, there is not a single instance of clarification about whom to classify as "white ${ }^{17}$. At most, enumerator instructions provided acceptable shorthand for reporting someone as « white » (e.g: " mark "b" for blanco »). While this was generally also true for the category « black » and, to a somewhat lesser extent, "Indian ", it is noteworthy that the self-evidence of whiteness was apparently too self-evident to mention, while the self-evidence of blackness or indianness might warrant explicit comment. For instance, the instructions to enumerators for the 1921 Guatemalan census stated matter-of-factly: «The characteristic marks of each race are well defined... For example, an individual of the yellow or black race is not easily confused with an Indian » (Guatemala. Dirección general de estadística 1924).

When enumerator instructions for reporting race went beyond issues of notation, it was usually to address the challenge of classifying " mixed race » individuals. The enumerator instructions for the 1876 Peruvian census, for example, read:

The column " Raza » has five subdivisions, the first for the white race, the second for the indian, the third for the black, the fourth for the mestiza, and the fifth for the asian. The first, second, third and fifth do not pose any difficulty whatsoever in the categorization of the individuals who belong to them. As for the mestiza race... it is to be understood that it includes all the mixtures [mezclas] without distinction (Perú. Dirección de estadística 1878, p. XXXIII).

The 1920 Panamanian census included « under the generic denomination of mestiza everything that is situated between one race and another, making use of the general understanding of the term » (Panamá. Dirección general del censo 1922, p. 18). The 1940 Brazilian census allowed enumerators to deal with « mixture » by filling in the blank with any term, then later aggregating all such open-ended responses into a catch-all mixed-race " pardo » category.

Enumerator instructions in Latin America reveal a concern with « accurate » classification of those of "mixed race », but the extent of this concern never approximated the classificatory obsession seen in enumerator instructions in United States censuses. In particular, there are no cases in Latin America where enumerators are explicitly cautioned to be wary of " misclassifying " those with any degree of "mixture» as "white». In the 1870 and 1880 US censuses, enumerators were told to « Be particularly careful in reporting the class Mulatto. The word here is generic, and includes quadroons, octoroons, and all persons having any perceptible trace of African blood. Important scientific results depend on the correct determination of this class in schedules 1 and $2 »{ }^{18}$. The explicit directives to US enumerators to be on the lookout for " traces " of "African blood » and the lack of such directives to enumerators anywhere in Latin America, suggests that ideas of " purity » figured much more centrally in the social 
definition of whiteness in the United States than in most of Latin America in this period ${ }^{19}$.

Also in contrast to the instructions for racial classification in the US, in some Latin American countries enumerators were instructed to prioritize social etiquette and deference to familial honor over concerns about accuracy in racial classification of respondents. A striking illustration of the concern about injury to personal honor in simply asking about « race » is the 1876 Peruvian census, which included this note of caution to enumerators:

No warning would be sufficient to impress on the Enumerators the delicacy with which they should proceed with this question, without ever allowing themselves to ask the person concerned directly and making the annotation in his presence without letting him see. Of course, when dealing with absent individuals or with inscriptions based on the declarations of third parties, asking about race is inevitable; but in such unavoidable cases, [the enumerator] should proceed with extreme tact, so much so that, even dealing with absentees, if possible the Enumerator, on most occasions, should avoid the question, whether because he knows the person or because, when speaking of the person his race is casually mentioned, or finally, by logical deduction that ancestors and descendents belong to the same race, as when he's dealing with the son of Whites or the parents of someone who is white; in which case the question would be unnecessary and insulting [hiriente]. ${ }^{20}$

That asking about absent family members of a white individual would be inherently insulting reveals how the notion of family honor was bound to the idea of whiteness. To avoid the " insult » of inquiring about « race », Latin American census takers were sometimes reminded to keep their racial classifications of the enumerated out of view, or to record individuals' race " in a discrete manner », as it was put to enumerators in the 1921 Guatemalan census.

When the array of direct " race » queries that appeared in Latin American census schedules between 1850-1950 are examined side by side, it is immediately clear that there is considerable variation across countries and over time in the specific methods and categories used to racially classify their populations. Yet the comparison also suggests that underlying this variation, certain basic assumptions about the nature of "whiteness 》 were shared among census-takers across the region. The mechanics of racial ascription in Latin America's censuses in this period suggest that at the level of the individual, « whiteness " was construed as an objective and observable personal trait. The self-evidence of "race " per se was understood to be especially self-evident in the case of "Whites ». And individual whiteness was strongly associated with notions of personal and familial honor.

Comparing the range of Latin American census " race » queries with those that have appeared in the censuses of the US, it is clear that for purposes of oflicial racial classification, « whiteness » was defined more narrowly in the latter context than in the former. While in the US census, the « white » racial category 
was supposed to be restricted to individuals without " any trace » of " nonwhite " ancestry, in the censuses of Latin American countries the "white" category did not necessarily carry this implication. Without doubt, the " white " racial category was construed more narrowly in some Latin American censuses than in others. But in no instance was « whiteness » explicitly defined as restrictively as it was in the censuses of the United States.

\section{THE VALUE OF WHITENESS: DESCRIBING AND INSCRIBING RACIAL HIERARCHY}

While the queries and categories used to collect racial statistics in Latin American censuses reveal underlying assumptions about the nature of whiteness, the formal presentation of census results yields insight into unspoken beliefs about the value of whiteness. As noted above, published volumes of censuses results were crafted as statistical portraits of the nation. In order to craft these national portraits, the masses of data collected by enumerators had to be aggregated, ordered, and packaged into the tidy rows and columns that comprise descriptive statistical tables. Census results do not present themselves; they are deliberately organized in ways that may reveal implicit assumptions of their creators ${ }^{21}$. The particular ways Latin American census-makers presented racial statistics in the published volumes of national census results suggests a broadly shared consensus about the position of whiteness in the "natural order » of racial hierarchy.

Among the Latin American census publications that present statistics describing the racial composition of the population, there is almost complete uniformity in listing the number of " Whites » first, regardless of the numerical distribution of the population among racial categories. That this presentational choice seemed « obvious » speaks to the successful naturalization of the idea that the category "white » belongs at the top of any racial hierarchy. Of course, in the broader public spheres of individual Latin American countries this notion was openly contested at several moments across this period. In the first decades of the twentieth century, in particular, intellectuals, political elites and social critics developed elaborate and nuanced arguments about the relative merits and deficits of different "races» and their potential contribution to national development ${ }^{22}$. "Whites» were not left out of these debates. There were often disagreements about the relative worth of different "kinds » of " whites ", disagreements that were analogous (though not identical) to those documented in historical scholarship on whiteness in the United States. But despite the contested and complicated ideological terrain in which individual census volumes were produced, when it came time to draw the tables reporting numerical results, the near universal tacit consensus was that « whites » should be listed first ${ }^{23}$. 
The most notable exception to this ordering trend proves the rule. In the 1921 Mexican census, the first after the Revolution of 1910, in the summary table titled « Razas », raza indigena is listed first, followed by raza mezclada, raza blanca, « all other races or unknown ", and "foreigners, without distinction by race" (México. Departamento de la estadística nacional 1928, p. 62). The Mexican Revolution, of course, extolled the indigenous past and constructed the ideological foundations for the construction of the Mexican raza cósmica; it was also virulently anti-imperialist and anti-colonialist, seeking to construct a new Mexican nationalism symbolically rooted in the glories of the indigenous past. The inversion of the « natural » order of racial categories was clearly a political act by those who produced the official statistics. And yet this deliberate disruption of the expected order of racial categories in the 1921 Mexican census serves to confirm the general rule, underscoring the extent to which the prioritization of " whiteness $"$ is taken for granted in the presentation of racial statistics across most of the region.

Notably, the privileging of whiteness sometimes comes across in the presentation of census results even in censuses that did not include a direct " race " query on the census schedule. To take one instance, Argentina's 1912 census of its territories included the query: "To what nation does the individual belong? ». The nominal categories included in summary tables of the population by nationality included only the names of recognized countries, thus ruling out official statistical recognition of Argentina's remaining indigenous peoples. Further, the nominal list of nationalities displayed in presenting the results was restricted to those countries that fell under the meta-categories " Europeans " and " Americans ». From data on nationality, thus circumscribed, the report on the 1912 census of territories constructed a description of the racial composition of the Argentine population. The twenty-five « European » and « American » nationality categories that appeared in the 1912 census report were lumped into groups of five razas. These included: 1) the "Latin race", which was subdivided into " Argentines », " Spanish-speaking Americans », and « Latinos of other languages »; 2) the « German race »; 3) the « Anglo-saxon race »; 4) the « Slavic race »; and 5) the "Scandinavian race» (Argentina. Dirección general de territorios nacionales 1914 , p. 26).

This particular strategy of deriving racial categories from European and American nationality categories effectively ruled out the statistical registering of non-European racial types in the Argentine population. Indeed, the text that accompanied the table admitted as much: « In speaking of races we do so taking into account the population nominally enumerated, omitting the indigena » (Argentina. Dirección general... 1914, p. 26). The fact that African-descent individuals were also omitted is not even explicitly mentioned (see Andrews 1980). This method of presenting racial statistics departed from the assumption that Argentina was always-already white. The statistical table conceded racial diver- 
sity within the nation, but a racial diversity that was nonetheless entirely " white ». The approach to presenting racial statistics in Argentina exemplifies how the categories used to display numerical data could render invisible entire segments of the population and, in so doing, (re)inscribe the conceptual pairing of the category « white » with the category « nation ${ }^{24}$.

The decisions made in the presentation of oflicial racial statistics in Latin American census reports from this period display a near consensual privileging of the "white " racial category. In this specific respect, the display of racial statistics in Latin American censuses also converges with the default privileging of the "white " category in statistical tables of census reports in the United States. At the same time, the organization of statistical tables reveals divergence across the region and over time in the conceptualization of the specific relationship between the category " white » and other racial categories, and between the category " white " and the nation as a whole. This variation in understandings of the boundaries of whiteness in relation to the nation is amplified in the narrative discussions that accompanied statistical tables in published census reports.

\section{THE BOUNDARIES OF WHITENESS: PROJECTING A IVHITER FUTURE}

In addition to pages and pages of statistical tables, published volumes of census results frequently contain carefully composed narrative analyses of the demographic « facts » made visible by the census. The analyses of racial statistics in these reports tend to focus heavily on the significance of demographic trends for the future racial composition of the nation. The demographic projections made in Latin American census reports reveal a shared understanding of the principal demographic processes fueling change in the racial composition of populations. Across the region, census reports pointed to the roles of differential fertility and mortality, immigration, and miscegenation in moving populations in a whiter direction.

Significantly, however, concurrence about the principal demographic mechanisms and direction of racial change led to different projected outcomes from the unfolding of demographic processes. In some countries, demographic trends were said to have already forged a homogenous " white » nation; in others, a " whitened » nation was projected in the future. In still others, it was predicted that the population would fuse into a homogenous " mixed » type; on the whole, such mestizo nations would be whiter than present populations, but they would never be just " white ». Among other things, these different projections reflected the historically specific ways that perceived demographic realities of " race » were refracted through distinct conjunctures of ideological, political and social struggle over the boundaries of citizenship and nationhood. 
When census reports drew attention to racial differences in rates of fertility or mortality, it was inevitably to note the quicker pace of « natural » increase among "Whites ». In Bolivia, for instance, the author of "A statistical sketch of Bolivia » concluded his discussion of " the races and their relations » with the presentation of comparative data on the rates of reproduction of " Whites » and Indios. Presenting numbers that purported to show that more " White » children were being born than indio children, the author concluded with an air of relief " that the White is multiplying more than the other » (Delance 1975 [1851], p. 205). In another example, the report on the 1920 Brazilian census presented tables of birth and death rates broken down by « race » to illustrate the higher growth rate of the « white » population. The report underlined the significance of these statistics: «In this work of aryanization of our people there are more energetic collaborators than the immigration of white races from Europe... there are natural and social selection, which accelerate extraordinarily among us the rapidity of the process of reduction of the ethnically inferior elements " (Brazil. Directoria geral de estatística 1922, p. 337).

A striking example of an explanation of " white " growth as a share of total population stemming from "natural selection 》 is found in the 1898 Cuban census. Taken immediately after US military occupation of Cuba, the published census report (which appeared in English) was composed by officers of the US War Department and clearly oriented to a North American audience. In reference to a table reporting a decline in the " colored " share of the Cuban population in the second half of the nineteenth century, the report noted:

Their diminution relative to the Whites, during the last half century, is doubtless but another illustration of the inability of an inferior race to hold its own in competition with a superior one, a truth which is being demonstrated on a much larger scale in the United States. (United States. War department... 1900, p. 97)

Unlike the other cases considered, this census reflected the imperialist and racist gaze of the US War Department. Notably, the "survival of the fittest » imagery in the Cuban census, which suggests explicit (and fatal) competition between " the races », contrasts with the image of more inadvertent and " pacific " processes of biological and social selection highlighted in the censuses of other Latin American countries. Nonetheless, the underlying notion that selective processes resulted in higher rates of " natural » growth for « Whites » was shared.

The white share of the population was also said to be growing in several Latin American countries due to European immigration. (The influx of non-European immigrants of various kinds, on the other hand, was rarely a focus of discussion.) European immigration as a mechanism of demographic change was emphasized in Brazilian census reports between 1890 and 1920. Following a table that displayed the absolute numbers of Europeans of different nationalities who entered into various Brazilian ports between 1908 and 1920, it was noted: « This 
admirable immigratory movement not only contributes to the rapid augmentation of the coefficient of the pure Aryan mass in our country; additionally, by crossing and re-crossing with the mestiça population, it contributes with equal rapidity to raising the Aryan element of our blood » (Brazil. Directoria geral de estatística 1922, p. 337).

Even in countries with a poor record attracting European immigrants, census reports might note the potential of such immigration to fuel racial-demographic change. The introduction to the 1893 Guatemalan census suggested, for example, that the "shadow » cast over Guatemalan development by the "indifference " and " passive attitudes » of the indigenous numerical majority could be counteracted [neutralizado], in part, « by European and North American immigrants, who were energetic and hardworking, if not as numerous as would be ideal ». In addition to their cultural and economic contributions to the vitality of the nation, immigrants would help to improve the "quality » [calidad] of the national population through their "contribution to national robustness » (Guatemala. Dirección general de estadística 1894, pp. 14-15).

European immigration - whether actual or potential - was described in many census reports as a means to augment the « white » share of national populations. European immigrants were seen to bode well for the whitening of national populations not only through the additive effect of a net inflow of « Whites » into the population, but also through an integrative effect, by « combining » with the native-born population. This points to a third demographic process identified in census reports as an engine of racial demographic change: miscegenation, or mestizaje.

In a wide array of contexts, mestizaje was reported to contribute to the overall whitening of the population through the assimilation (disappearance) of indigenas or negros. The fact that « mixture » also entailed reducing the relative number of "Whites", on the other hand, was not usually mentioned. This bias in emphasis in Latin American census reports reflects the fact that despite its semantic neutrality, mestizaje was typically construed as a socio-demographic process that moved populations in a whiter direction. In principle, and in its most idealized formulations, mestizaje implies a neutral fusion of distinct " kinds » into a unique new « kind » that is better than the sum of its parts. Historically and in practice, however, mestizaje - as a socio-demographic process and as official ideological trope - has tended to privilege and promote the « white » component of the $\operatorname{mix}^{25}$.

In a few cases, mestizaje was explicitly described as a demographic process that would eventually yield a whitened population. The 1920 Brazilian census, cited above, is the most blatant example of this view. The idea that racial mixture was whitening Brazil's population flipped the "hypodescent rule » that was institutionalized in law throughout most US states in this period on its head. In Brazil, when «Whites » mixed with «non-Whites», the result was not the 
pollution and degeneration of whiteness, but the improvement, regeneraton, and eventual dissipation of non-whiteness.

Mestizaje was more often construed in census reports to be moving the aggregate population in a whiter direction, but not necessarily towards a thoroughly whitened population in the future. Even in countries and at historical moments when it was celebrated as constitutive of nationality, mestizaje was usually described in census reports as a process that pulled the population irreversibly away from the categories « black » and « indian », whether culturally, biologically, or simply numerically. In many Latin American census publications - including cases where the census did not collect data that could speak to the question - mestizaje was credited with the decline in number of indigenous peoples within the national territory. Venezuelan national censuses, for example, reported rough estimates of the indigenous population that purported to demonstrate their rapid blending into the general population (Venezuela. Dirección general de estadística 1938). The introduction to the 1893 Guatemalan census, to take another example, affirmed that two-thirds of the national population was indigena, " but in some districts, and especially near the centers of the white population, the [indigena] race has suffered declines as a consequence of mixing [cruzamento] in various degrees") (Guatemala. Dirección general de estadística 1894, p. 15). Similarly, in Argentina, the report of an estimated total of 58,979 indigenas in the Argentine territories was immediately qualified with the claim that although the numbers were not diminishing « with the rapidity that was believed », the indigenas « become mixed [se mestizan], become civilized, and become diluted in the general mass of the population » (Argentina. Dirección general... 1914, p. 34).

Commentaries in official census reports often cheered the projected disappearance of indigenas as a distinctive element in the national population, even as they celebrated the contribution of indigenous groups to defining the essence of the nation. In the 1900 Bolivian census, to take one example, the observation that the diverse " indigenous races » of Bolivia were destined to disappear was followed by the claim that each of them had « contributed to stamping (imprimir) the peculiar character of the nationality that has formed within the limits that today constitute the Republic of Bolivia » (Bolivia. Oficina nacional... 1973 , p. 25). Notably, this same census reported that indigenas made up the majority $(50.91 \%)$ of the population ${ }^{26}$. The raza mestiza was the next largest group ${ }^{27}$. Nonetheless, the census report assured readers that the numerical minority of " whites » remained firmly in control of the country: " the White race, descendent of the Spanish, whose most illustrious names are found here in profusion, is the smallest in number but has retained over all the others the supremacy [the white race] obtains in all places... » (Bolivia. Oficina nacional... [1973] 1902, p. 30).

While the 1900 Bolivian census maintained a clear divide between " Whites » and mestizos, in other contexts, mestizaje was understood to blur the distinction 
between these two categories, while leaving the line demarcating « Indian » from everyone else intact. In one example, the 1940 Peruvian census reported a major shift in the racial composition of the population between 1876 and 1940 using a bar graph that combined the " white » and « mestizo » totals in a single bar labeled blanca $y$ mestiza. The growth of the blanca y mestiza population over time was measured against the diminishing size of the population categorized as india. The lumping of blanca y mestiza to report the trajectory of racial demographic change implied the fuzziness - even irrelevance - of the boundary between them, while their combined juxtaposition to the category india made clear that the result of mestizaje is an approximation towards whiteness.

In another example, the 1893 Guatemalan census report explained that the category ladino referred to the combination of « Whites » and « the mixture of the European with the indigena ». Treating them together made sense, the report continued, because « the mixture of the European with the indigenous race has not produced either facultative decrease nor intellectual or moral debilitation » (Guatemala. Dirección... 1894, p. 14). At the same time that the boundary between « white » and mestizo was downplayed through use of the category ladino in the narrative analysis, the boundary between ladino and indigena was maintained stark and clear - though by no means impassable. Guatemala was portrayed as a dual society, composed of two " races »-ladinos and indigenas - that did not « move to the same compass » (Guatemala. Dirección... 1894, p. 15) ${ }^{28}$. The differences between them were not, however, « organic »: « The Indians who enter into any type of immediate relations with the families or services of the active society, quickly develop an amount of energy disproportionate to what you would presume from a glance at the race as a whole, and this phenomenon is especially noticeable among the Indian women $»$. Through both sexual and social contact, the boundary between indigenas and ladinos could be easily crossed, though only in one direction.

In most cases where mestizaje was highlighted as a mechanism of racial change, it was construed as one demographic process among others moving the aggregate population in a whiter direction. Mestizaje " explained» the shrinking numbers of "Blacks » and "Indians », while simultaneously documenting the particular blend of human types that made up the «not exactly white... or almost white » national mestizo type (Martínez-Echazábal 1998, p. 34). Once again, the 1921 Mexican census stands out as an exception that proves the rule. In contrast to the more common tendency to conceive mestizaje as means of collective approximation towards whiteness, the 1921 Mexican census emphasized mixed-ness as an end point in itself. In this version of mestizaje, the distance between mestizo and indigena was symbolically shorter than the distance between mestizo and "white ». Matter-of-factly, the census reported that the majority of the Mexican population corresponded to the raza mezclada, followed by the raza indigena and then the raza blanca. The blunt 
reporting of absolute numbers of each "race " was followed by a lengthy discussion of the various indigenous languages and archaeological treasures to be found in different parts of Mexico. The statistical description of a predominantly mestizo present population was thus followed by the narrative evocation of the glorified indigenous past upon which modern Mexican mestizo national identity was constructed (México. Departamento de la estadistica nacional 1928, pp. 51-53).

Stepping back, it becomes clear that discussions of racial demographic trends in Latin American censuses in this period hinge on two distinct, even contradictory, conceptions of the character of the boundaries of whiteness. On the one hand, analyses of differential fertility, mortality, and immigration as sources of growth in the relative size of the "white " population belie a vision of racial boundaries as solid, stable, enduring ${ }^{29}$. Change in the racial composition of the nation is envisioned to occur through additive increase in the number of "Whites » relative to other racial categories, while the boundaries between categories remain the same. On the other hand, analyses of mestizaje as fueling racial demographic change tend to imply a vision of the boundary of whiteness as more porous, malleable, even dissolvable in some cases. Aggregate shifts in the population in the direction of whiteness take place through integrative increase in the share of the population that is neither "black » nor "Indian ». Rarely, censuses depict mestizaje as a demographic process that blurs all racial boundaries with equanimity, resulting in population projections that tack directly in between the constituents parts to the racial mix. More often, censuses show mestizaje to blur the boundary between « white » and mestizo while leaving other boundaries intact, resulting in population projections that gravitate towards a whiter - if never fully whitened - future.

\section{DISCUSSION AND CONCLUSION}

The survey of efforts to classify and quantify « whiteness » in Latin America's national censuses from 1850-1950 makes clear that there is significant variation across the region and over time in the nuances of racial thought that informed the production of racial statistics. Indeed, on one level, this analysis confirms the truism that it is always hazardous to venture generalizations about " race » in Latin America as if Latin America were a single monolithic and coherent unit. Clearly, to properly understand and explain the specific content and sociopolitical significance of any of the individual census volumes considered here requires rigorous historical analysis of the scientific, political, and cultural contexts of production, reception, and dissemination. The broad comparative perspective adopted in this article is no substitute for deep historical research on individual cases. 
Yet the sharply focused but wide-angle analytical lens deployed in this essay productively complements such idiographic research. The broad comparative analysis of the meaning and measure of " whiteness » in Latin American censuses illuminates several fundamental points of convergence in the racial understandings that informed the production of statistical portraits of Latin American nations in this period. Taking stock of these points of convergence enriches existing and future idiographic research, by bringing into focus the specificities of individual cases that are most surprising - and thus sociologically interesting - in comparative and historical perspective. Taking stock of shared assumptions about the meaning of whiteness in Latin American census production also illuminates key contrasts - but also significant similarities - to the meaning of whiteness in censuses in the United States. Consideration of the similarities with the United States, in particular, suggests the potential for development of a Latin American analog to parts of the intellectual agenda charted by "whiteness studies » in the United States.

The comparative review of the production of racial statistics in Latin American censuses brings to light certain fundamental commonalities in tacit assumptions about the nature, value and boundaries of whiteness. With regard to understandings of the nature of whiteness, the analysis revealed that those who crafted census questionnaires presumed that enumerators did not need guidance to identify "Whites » in the population. Whiteness was treated as if it were completely self-evident, a property of individuals that could easily be read by enumerators from bodily and, in some cases, societal cues. With regard to assumptions about the value of whiteness, analysis of statistical tables revealed a near universal consensus that « white » belongs first among racial « kinds ». With regard to conceptions of the boundaries of whiteness, analysis of demographic explanations for shifts in the racial composition of populations revealed that almost all countries in this period pronounced, projected or aspired to collective demographic movement in a whiter direction.

Analysis of the measure and meaning of whiteness in Latin American censuses also revealed that multiple and sometimes contradictory understandings of whiteness coexisted within individual census volumes, with no apparent tension. As noted above, accounts of racial demographic shifts fueled by « natural » increase, immigration, and mestizaje implied simultaneous acceptance of two very different conceptions of the character of white racial boundaries. In addition, while at the individual level whiteness was treated as self-evident and stable, an enduring characteristics of particular human beings, at the collective level, whiteness was construed as variable, a malleable and (in some versions) achievable trait of national populations. While perhaps not surprising, the easy coexistence of alternative conceptions of whiteness within individual Latin American census volumes underscores the complexity - and slipperiness - of racial categories, both as they are used in practice, and as objects of social scientific analysis. 
Cross-cutting the historical particularities of individual cases, certain fundamental understandings of " whiteness " pervade the production of racial statistics in Latin American censuses in this period: whiteness is obvious, whiteness is privileged, and whiteness is desired. Notwithstanding the myriad ways this generalization would be specified as applied to any particular case, there is a broad « family resemblance » across the region in the key tacit assumptions about the nature of whiteness that inform the production of racial statistics in national censuses.

The "family resemblance » in tacit understandings of whiteness that informed statistical production in Latin America appears more starkly when the scope of analysis is extended to include the United States. In addition to the specific points of contrast specified above, the treatment of whiteness in US and Latin American censuses diverges sharply in one respect in particular. The conception of whiteness as a collective trait that could be demographically approximated or achieved - a conception found in different variants in census volumes throughout much of Latin America - ran counter to the dominant notion of whiteness operationalized in the censuses of the United States. In the US Census in this period, whiteness was not a collective status to achieve, but a national trait to preserve. Demographic trends like immigration and miscegenation that were hailed in many Latin American censuses as contributions to national (qua racial) progress, appeared in US censuses as threats to the national racial order.

Yet perhaps in a more fundamental respect, tacit beliefs about whiteness contained in US and Latin American censuses are very much alike. As in almost all Latin American censuses in this period, in US censuses the "white " racial category always came first. It was listed first in enumerator instruction and questionnaires, in statistical tables reporting results, and in narrative lists of racial categories. The place of « white » in the « natural order » of racial categories was too obvious to be questioned. Ideologically organized statistical tables that inscribed a preference for whiteness were presented and, we might reasonably assume, read as neutral descriptions of numerical facts.

Of course it is precisely the invisibility of the preference for whiteness - exemplified in the seeming naturalness of placing the " white " category first in tables of racial statistics - that helped to inspire and is directly challenged by much whiteness studies scholarship in the United States. In recent years, especially, this scholarship has been less concerned with documenting the open and explicit history of racial exclusion and violence in America, and more concerned with understanding the dimensions of white racial privilege and domination that are not generally perceived as such. To date, scholarship on race in Latin America has paid more attention to the former type of dynamics than to the latter.

Here is where the identification of a shared understanding of the « natural order " of racial categories in censuses from across the Americas generates a promising new avenue of research for students of Latin America. As in the US, 
the analysis of explicit discourses, practices, and experiences of racial marginalization in Latin America would be advanced through simultaneous analysis of socially invisible forms of racial preference, privilege and domination. By objectifying " whiteness », making tacit assumptions explicit, naming the « obvious », and identifying racial privileges that are not recognized (by those who enjoy them) as such, research on the social significance of whiteness in Latin America might help to denaturalize the hierarchical order that today still remains « the natural order of things » throughout so much of the region. *

* Manuscrit reçu en février 2009, accepté pour publication en septembre 2009.

\section{NoTES}

This article was originally prepared for the conference « Des catégories et de leurs usages dans la construction sociale d'un groupe de référence: "race", "ethnie" et "communauté" aux Amériques ", held at the EHESS, Paris, 13-14 December, 2006. I am very grateful to the conference organizers, Véronique Boyer and Sara Le Menestrel, for the invitation to participate, and to the other conference attendees for the stimulating exchange of ideas. I also wish to thank Jim Cohen and Carmen Salazar-Soler for their thoughtful written comments to the original conference paper, and Peter Kolchin, Daniel Sabbagh, Charles Hale, Peter Wade, Peter Fry, and Juan Carlos Garavaglia for their constructive questions and critiques. Thanks are also due to the anonymous reviewers for the Journal de la Société des Américanistes for their thoughtful suggestions for improving the essay. Research for this article was supported in part by a grant from the Graduate School at the University of Wisconsin, Madison.

1. Foundational works include Roediger (1991; 2005), Dominguez (1994), Ignatiev (1995), Jacobson (1999). For critical review of contributions to literature on whiteness in the United States, see Bonnett (1998), Kolchin (2002), Guglielmo (2003).

2. See Kolchin (2009) for a review of recent contributions.

3. Space constraints do not permit a full listing of the many notable contributions to this literature. Important works include Wade (1993), Skidmore (1993), Mallon (1995), de la Fuente (2001), Andrews (2004), Larson (2004) and the collection of essays compiled by Appelbaum et al. (2003).

4. For more on this approach to the analysis of censuses, see, inter alia, Hirschman (1987), Patriarca (1996), Kertzer and Arel (2002), Otero (2006).

5. To explain changes in census questions and categories within countries over time requires a deep engagement with the historiography to understand how developments in the political, scientific, and cultural fields shaped census-taking practices. I have attempted such an analysis of the Brazilian case elsewhere (Loveman 2009).

6. Many of the nineteenth-century censuses reported in Figure 1 - and some early-twentieth century censuses as well - have been disavowed by contemporary national statistics agencies as unreliable and incomplete. But the technical and procedural shortcomings of early censuses do not hinder their analysis as political and cultural artifacts. For a few of the early nineteenth-century cases, there are documented reports of a national census but little information beyond that. These cases require additional research.

7. Note that census queries related to cultural characteristics, such as language used in the home, dietary choices, or clothing, are not reported in Figure 1. Such queries are directly relevant to understanding how Latin American statistics agencies conceive (and construct) lines of " difference " within their respective populations, a larger project which I tackle in another context. The more 
narrowly circumscribed focus of the present analysis, however, is the subset of Latin American censuses that attempt to directly discern the " race " or " color » of individuals in the population.

8. Chile's early census efforts are analyzed in Jaramillo (2004). Provincial and local level enumerations took place in several Latin American countries during these decades, but for most countries, the aspiration to conduct a national census did not bear fruit until the second part of the nineteenth century or beginning of the twentieth.

9. Most countries dropped direct race queries from census questionnaires for a combination of pragmatic, political and international reasons (see Loveman 2001, pp. 332-334).

10. On the institutionalization and international diffusion of modern census-taking, see Ventresca (1995).

11. There is a growing body of research on the connections between census-taking and state and nation-building in individual Latin American countries. See Clark (1998), Botelho (1998), Jaramillo (2004), Otero (2006), Raga (2008).

12. In addition to translation of census publications into French (the nineteenth-century language of international diplomacy), standardized methods, form, and presentation of results all contributed to the international legibility of census publications.

13. In practice, of course, enumerators may have allowed household heads or others to fill out their own forms in some contexts. But officially, the enumerator was supposed to assign each individual to the " correct » racial category.

14. Of the 190 national censuses included in my review, I was able to obtain a copy of the original census schedule for 115 . Of those with a direct race or color question prior to IVIVII, 56 include some kind of written instructions to enumerators pertaining to the race query.

15. Conversely, in a few instances tables reporting census results at the provincial level report the number of amarillo individuals even though amarillo was not an allowable category according to official enumerator instructions. Such discrepancies speak to the disjuncture between official visions of the relevant racial kinds that make up the nation and the much broader array of ethnoracial distinctions informing social interactions in daily life.

16. This claim is based on analysis of the subset of 50 censuses for which I was able to consult the original census schedule for the official categories used by enumerators. Of these there are four cases where a " white » category was not included in the oflicial category set: Guatemala 1880; Honduras 1887; Bolivia 1950, and Colombia 2005 (the latter case corresponds to a different historical moment in the history of racial enumeration in Latin America, see Loveman 2001, p. 336).

17. In this respect, instructions for racial classification on Latin American censuses mirrored those in the United States, where clarification for how to identify " Whites » is also conspicuously absent from enumerator instructions (Nobles 2000, pp. 187-190).

18. The « mulatto » category was eliminated from the US census in 1900. It returned in 1910 and 1920 , but in 1930 " Negro » became an all-encompassing category for individuals showing any trace of African ancestry. On race classification in the US census, see Lee (1993), Goldberg (1997), Anderson and Fienberg (2000), Nobles (2000), Schor (2009). The exclusion of a " mixed race » category of any sort for most of the twentieth century in US censuses stands in marked contrast to racial classification practices in Latin America during the same period.

19. This is not to deny that ideas of "blood purity " informed - and continue to inform - ideas about race in the social thought and practices of some sectors of Latin American societies. The point here is that the weight placed on " purity " as a criteria for eligibility in the " white " census category was much greater in the US.

20. This cautionary tone was reiterated in the instructions to enumerators for the 1940 Peruvian census. The instructions read: « Is [the individual] white, indian, black, yellow or mestizo? - It is not necessary to ask this question when the individual is seen; the Enumerator will record the data according to his personal judgement. Persons without a defined race such as white, indian, black or yellow will be reported as mestiza » (Perú. Dirección de estadística 1944, p. 598).

21. See Goldstein (2000), Zerubavel (1996), Hirschman (1987), Monmonier (1991), Starr (1987). 
22. From the large and still growing literature on this topic, see especially Graham (1990), Helg (1990), Stepan (1991), Skidmore (1993), Martinez-Echazábal (1998), Wade (1993), Lesser (1995; 1999).

23. The dividing lines within the " white " category were often understood to be racial lines, as well as national and religious. See Kolchin (2002); Guglielmo (2003). On debates over the merits of different kinds of « whites » in Latin America, see especially Lesser (1995; 1999); Skidmore (1993).

24. On ideas of race, nation and the census in Argentina, see Otero (2006), Andrews (1980), Gootenberg (1993).

25. On the subordinate position of blackness and indianness in national ideologies of mestizaje, see especially Martínez-Echazábel (1988). This racial hierarchy-within-mixture is sometimes inverted, especially in performative spaces (Wade 1993). But such moments of inversion testify to the naturalized racial hierarchy within « mestizaje » that prevails more broadly.

26. The numerical majority of indigenas might help account for the pages devoted to describing the virtuous characteristics of the various pueblos, branches [ramas], and " nations » of Bolivia's indigenous peoples - only $9 \%$ of whom, according to the census, still lived « in a state of barbarism » (Bolivia. Oficina nacional... 1973, p. 28).

27. The census text further explained that the mestizo, known as cholos in Bolivia, exhibited the character of the Spanish and indigenous races from which it emerged, « even though their features and color are closer to those of the indian » (Bolivia. Oficina nacional... 1973, p. 30).

28. The text also notes a few other marginal "types» in passing, including the "not very perceptible group of mixed indigena and negro, that of blanco and negro, and the successions of these two ".

29. On the essentialist assumptions embedded in conventional methods for projecting racial populations forward, see Hirschman (2002).

\section{REFERENCES CITED}

ANderson Margo J. and Stephen E. FienberG

$2000 \quad$ Who counts? The politics of census-taking in contemporary America, Russell Sage Foundation, NewYork.

ANDREws George Reid

1980 The Afro-Argentines of Buenos Aires, University of Wisconsin Press, Madison.

2004 Afro-Latin America, 1800-2000, Oxford University Press, Oxford.

Appelbaum Nancy P., Anne S. Macpherson, Karin A. Rosemblatt (eds)

2003 Race and nation in modern Latin America, University of North Carolina Press, Chapel Hill.

Argentina. Dirección general de territorios nacionales

1914 Censo de población de los territorios nacionales, República Argentina, 1912, Ministerio del Interior, Imp. G. Kraft, Buenos Aires.

BoLivia. Oficina nacional de inmigración, estadística y propaganda geográfica

1973 Censo general de la población de la República de Bolivia según el empadronamiento de 1 de septiembre de 1900, Editorial Canelas, Cochabamba. 
BONNETT Alastair

1998 "Who was white? The disappearance of non-European white identities and the formation of European racial whiteness ", Ethmic and Racial Studies, 21 (6), pp. 1029-1055.

Botelho Tarcísio Rodrigues

1998 População e nação no Brasil do século xIx, Universidade de São Paulo, São Paulo.

Brazil. Directoria geral de estatística

1922 Recenseamento do Brazil Realizado em 1 de Setembro de 1920, Typografia da Estatística, Rio de Janeiro.

Clark A. Kim

1998 "Race, "culture", and mestizaje: the statistical construction of the Ecuadorian nation, 1930-1950 », Journal of Historical Sociology, 11 (2), pp. 185-211.

De La Fuente Alejandro

2001 A nation for all: race, inequality and politics in twentieth-century Cuba, University of North Carolina Press, Chapel Hill and London.

Delance José M.

1975 Bosquejo Estadístico de Bolivia, Universidad Boliviana, La Paz [1851].

Domínguez Virginia R.

1994 White by definition: social classification in Creole Louisiana, Rutgers University Press, New Jersey.

GoldBerg David Theo

1997 Racial subjects: writing on race in America, Routledge, New York.

Goldstein Joshua R.

2000 "What's in an order? Reading statistical tables as mental artifacts », Paper presented at the 2000 meeting of the American Sociological Association, Washington DC, August 12-16, 2000.

Gootenberg Paul

1993 Imagining development: economic ideas in Peru's " fictitious prosperity " of Guano, 1840-1880, University of California Press, Berkeley.

GOYER Doreen S. and Eliane DomschKe

1983 The handbook of national population censuses: Latin America and the Caribbean, North America, and Oceania, Greenwood Press, Westport Conn.

GraHAM Richard

1990 The idea of race in Latin America, 1870-1940, University of Texas Press, Austin.

Guatemala. Dirección de estadística

$1894 \quad$ Censo general de la República de Guatemala levantado el 26 de Febrero de 1893 por la Dirección general de estadistica y con los auspicios del presidente 
constitucional, General Don José María Reina Barrios, Typ. « Nacional », Guatemala.

1924 Censo de la población de la República levantado el 28 de Agosto de 1921, Typ. « Nacional », Guatemala.

Guglielmo Thomas A.

2003 White on arrival: Italians, race, color and power in Chicago, 1890-1945, Oxford University Press, Oxford.

Helg Aline

1990 " Race in Argentina and Cuba, 1880-1930 », in Richard Graham (ed.), The idea of race in Latin America, 1970-1940, University of Texas Press, Austin, pp. 37-69.

HiRsCHMAN Charles

1987 «The meaning and measurement of ethnicity in Malaysia: an analysis of census classifications ", Journal of Asian Studies, 46, pp. 555-582.

2002 «Race and ethnic population projections: a critical evaluation of their content and meaning ", in Nancy A. Denton and Stewart E. Tolnay (eds), American diversity: a demographic challenge for the twenty-first century, State University of New York Press, Albany NY, pp. 51-72.

IGNATIEv Noel

1995 How the Irish became white, Routledge, New York.

JACOBSon Matthew Frye

1999 Whiteness of a different color: European immigrants and the alchemy of race, Harvard University Press, Cambridge.

JARAMILlo Andrés Estefane

2004 "Un alto en el camino para saber cuántos somos": los censos de población y la construcción de lealtades nacionales, Chile, Siglo XIX », Historia, 37 (1), pp. 33-59.

Kertzer David I. and Dominique Arel (eds)

2002 Census and identity: the politics of race, ethnicity, and language in national censuses, Cambridge University Press, Cambridge.

\section{Kolchin Peter}

2002 "Whiteness studies: the new history of race in America ", Journal of American History, 89 (1), pp. 154-173.

2009 "Whiteness studies", Journal de la Société des Américanistes, 95 (1), pp. 117-163.

LARSON Brooke

2004 Trials of nation making: liberalism, race, and ethmicity in the Andes, 1810-

1910, Cambridge University Press, Cambridge.

LEe Sharon M.

1993 "Racial classifications in the US census: 1890-1990 », Ethmic and Racial Studies, $16(1)$, pp. 75-94. 
LESSER Jeffrey

1995 Welcoming the undesireables: Brazil and the Jewish question, University of California Press, Berkeley.

1999 Negotiating national identity: Immigrants, minorities, and the struggle for ethnicity in Brazil, Duke University Press, Durham and London.

LOVEMAN Mara

2001 Nation-State building, "race ", and the production of official statistics: Brazil in comparative perspective, $\mathrm{PhD}$, University of California, Los Angeles.

2009 "The race to progress: census-taking and nation-making in Brazil, 1870-1930", Hispanic American Historical Review, 89 (3), pp. $435-470$.

MALLON Florencia

1995 Peasant and nation: the making of postcolonial Mexico and Peru, University of California Press, Berkeley.

MARTíneZ-EchazÁbal Lourdes

1998 "Mestizaje and the discourse of national/cultural identity in Latin America, 1845-1959 », Latin American Perspectives, 25 (100), pp. 21-42.

México. Departamento de la estadística nacional

1928 Resumen del censo general de habitantes, de 30 de Noviembre de 1921, Talleres Gráficos de la Nación, Mexico.

MONMONIER Mark

1991 How to lie with maps, University of Chicago Press, Chicago.

NoBles Melissa

2000 Shades of citizenship: race and the census in modern politics, Stanford University Press, Stanford.

OTERo Hernán

2006 Estadistica y nación: una historia conceptual del pensamiento censal de la Argentina moderna 1869-1914, Prometeo Libros, Buenos Aires.

Panamá. Dirección general del censo

1922 Boletin $n^{\circ}$ 1. Censo demográfico de la provincia de Panamá, 1920, Imprenta Nacional, Panama.

Patriarca Silvana

1996 Numbers and nationhood: writing statistics in nineteenth-century Italy, Cambridge University Press, Cambridge.

Perú. Dirección de estadística

1878 Resumen del censo general de habitantes del Perú, hecho en 1876, Imprenta del Estado, Lima.

1944 Censo nacional de población y ocupación, 1940, Imprenta del Estado, Lima.

Platt Lyman D.

1989 Latin American Census Records, Instituto Genealógico e Histórico Latinoamericano, Utah [second edition]. 
RAGA José

2008

« Ideólogos del Leviatán. Estadística y sociedad en Perú (1791-1876) », in Carlos Aguirre and Carmen Mc Evoy (eds), Intelectuales y poder: Ensayos en torno a la república de las letras en Perú e Hispanoamérica (ss. XVI-XX), Instituto Francés de Estudios Andinos, Lima, pp. 151-172.

ROEDIGER David

1991 The wages of whiteness: race and the making of the American working class, Verso Books, London and New York.

2005 Working toward whiteness: how America's immigrants became white, Basic Books, New York.

ScHor Paul

2009 Compter et classer. Histoire des recensements américains, 1790-1940, Éditions de l'EHESS, Paris.

SKIDMORE Thomas

1993 Black into white: race and nationality in Brazilian thought, Oxford University Press, Oxford [second edition].

Starr Paul

1987 «The sociology of official statistics», in William Alonso and Paul Starr (eds), The politics of numbers, Russell Sage Foundation, New York, pp. 7-57.

STEPAN Nancy L.

1991 The hour of eugenics: race, gender; and nation in Latin America, Cornell University Press, Ithaca.

United States. War department

1900 Cuban Census Office, 1900. Census of Cuba, 1899, Govt. Print. Off., Washington.

Venezuela. Dirección general de estadística

1938 Resumen general del sexto censo de población, 26 de diciembre de 1936, Ministerio de Fomento, Tip. Garrido, Caracas.

Ventresca Marc J.

1995 When states count: institutional and political dynamics in modern census establishment, 1800-1993, PhD, department of sociology, Stanford University, Stanford, CA.

WADE PETER

1993 Blackness and race mixture: the dynamics of racial identity in Colombia, Johns Hopkins University Press, Baltimore and London.

Zerubavel Eviatar

1996 "Lumping and splitting: notes on social classification », Sociological Forum, 11 (3), pp. 421-433. 